\title{
Efektivitas pelapisan benih kelengkeng (Dimocarpus longan Lour.) menggunakan kombinasi jenis bahan pelapis dengan ekstrak biji selasih dan wadah simpan berbeda
}

\section{(Coating effectivity on longan seed with a combination of types of coating materials with addition of basil seed extract and different storage containers)}

\author{
A. N. Alamsyah, W. Slamet, dan F. Kusmiyati \\ Agroecotechnology, Faculty of Animal and Agricultural Sciences, Diponegoro University \\ Tembalang Campus, Semarang 50275 - Indonesia \\ Corresponding E-mail: anggihnoor31@gmail.com
}

\begin{abstract}
ABTRACT
The research was intended to maintain the quality of longan seed viablity for 30 days of storage with a combination of types of coating materials with addition of basil seed extract and different storage containers. The research used a factorial experiments in completely randomized designs of $4 \times 3$ with 4 replications. The first factor was the effect of coating (T) which the treatments were T1 (control), T2 (arabic gum + basil seed extract), T3 (alginate + basil seed extract), T4 (Carboxy Methyl cellulose + seed extract). The second factor was the storage container $(\mathrm{P})$ which the treatments were brown blur paper (P1), poripropylene plastic (P2), and aluminum foil (P3). Observation parameters were seed water content, germination, vigor index, and maximum growth potential. The data were analyzed using analysis of variance and continued by Duncan Multiple Range Test. The result of this research shows that the treatment of CMC coating formulation with seed extract of basil on aluminum foil container can maintain viability of longan seed during storage with the result of moisture content of longan seeds was $47.68 \%$, germination $83.75 \%$, The seed vigor index was $53.75 \%$ and the maximum growth potential was $90 \%$.
\end{abstract}

Keywords: Seed viability, longan, effect of coating, storage container

\begin{abstract}
ABSTRAK
Penelitian ini bertujuan untuk mempertahankan kualitas viabilitas benih kelengkeng selama 30 hari penyimpanan dengan kombinasi jenis bahan pelapis yang ditambahkan ekstrak biji selasih dengan wadah simpan yang berbeda. Penelitian menggunakan rancangan rancangan acak lengkap pola faktorial 4x3 dengan 4 kali ulangan, faktor pertama yaitu pengaruh pelapisan (T) dengan perlakuan T1 (kontrol), T2 (Arabic gum + ekstrak biji selasih), T3 (Alginat + ekstrak biji selasih), T4 (Carboxyl Methyl cellulose + ekstrak biji selasih). Faktor kedua wadah simpan (P) yaitu kertas buram coklat (P1), plastik poripropilen (P2), dan aluminium foil (P3). Parameter pengamatan berupa kadar air benih, daya kecambah, indeks vigor, dan potensi tumbuh maksimum. Data dianalisis ragam dan dilanjutkan dengan uji lanjut Duncan Multiple Range Test. Hasil penelitian menunjukkan bahwa perlakuan formulasi pelapisan CMC dengan ekstrak biji selasih pada wadah simpan alumunium foil dapat mempertahankan viabilitas benih kelengkeng selama penyimpanan yang paling baik dengan hasil kadar air benih kelengkeng pada perlakuan tersebut yaitu sebesar 47,68 \%, daya berkecambah $83,75 \%$, indeks vigor benih $53,75 \%$ dan potensi tumbuh maksimum yaitu sebesar $90 \%$.

Kata kunci : Viabilitas benih, kelengkeng, formulasi pelapisan, wadah simpan
\end{abstract}




\section{PENDAHULUAN}

Buah kelengkeng secara komersial bernilai tinggi di pasar internasional. Di Indonesia, buah lengkeng termasuk buah yang banyak digemari oleh masyarakat. Permintaan buah ini cenderung meningkat dari tahun ke tahun seiring perkembangan trend buah di kalangan masyarakat. Impor buah lengkeng ke Indonesia pada tahun 2013 sebanyak 50.105.956 ton yang tersebar masuk melalui Pelabuhan Belawan, Tanjung Priok, Tanjung Emas, Batam, dan Tanjung Perak Surabaya (Barantan, 2014). Impor buah kelengkeng melalui Pelabuhan Tanjung Perak tahun 2013 sebanyak 19.100.797 ton dan berasal dari negara Cina, Vietnam serta Thailand (BBKP Surabaya 2014). Upaya peningkatan produksi kelengkeng tidak terlepas dari penyediaan bibit kelengkeng untuk tanam maupun sebagai batang bawah yaitu dengan kegiatan mempertahankan viabilitas benih kelengkeng.

Benih kelengkeng yang memiliki kualitas viabilitas benih yang baik pada saat awal penanaman hingga perawatan yang baik sampai panen akan menghasilkan produksi lengkeng yang maksimal. Benih lengkeng yang terinfeksi oleh cendawan dengan persentase infeksi mencapai $100 \%$ pada lama simpan selama 3 minggu yang menyebabkan penurunan viabilitas benih lengkeng (Dita, 2011). Salah satu teknologi yang dapat digunakan untuk mempertahankan kualitas viabilitas benih adalah dengan pelapisan. Pelapisan benih adalah pemberian lapisan pada permukaan benih yang berfungsi untuk mempertahankan masa dormansinya (Widyawati et al., 2009). Jenis bahan perekat yang umum digunakan untuk pelapis benih adalah diatomaceous earth, charcoal, arabic gum, polyvinyl alkohol, Carboxyl Methyl Cellulose (CMC), dan alginat yang dapat mempertahankan viabilitas benih (Kuswanto, 2003). Ekstrak biji selasih juga dapat digunakan sebagai pelapis benih untuk mempertahankan viabilitas benih selama penyimpanan karena memiliki kandungan komponen yang berasal dari golongan triterpenoid yang menghambat pertumbuhan bakteri pada benih (Harmely et al., 2014).

Benih kelengkeng termasuk benih rekalsitran, dalam usaha memperpanjang daya hidup benih rekalsitran dapat dilakukan dengan pelapisan dan pengemasan benih yang baik untuk mempertahankan kualitas viabilitas benih (Rina et al., 2012). Solusi untuk mempertahankan viabilitas benih yang baik adalah dengan menggunakan formula pelapisan antara lain sebagai perekat yaitu Carboxyl Methyl Cellulose, arabic gum, alginat dan kitosan (Ilyas, 2012). Penggunaan bahan kemasan yang tepat dapat melindungi benih dari perubahan kondisi lingkungan simpan yaitu kelembaban nisbi dan suhu. Kemasan yang baik dan tepat dapat menciptakan ekosistem ruang simpan yang baik bagi benih dan dapat mempertahankan kadar air benih sehingga benih dapat disimpan lebih lama (Oktralixon et al., 2015). Wadah simpan kemasan untuk benih dapat menggunakan kertas, plastik poripropilen dan aluminium foil. Kertas merupakan kemasan simpan yang bersifat porous, digunakan secara luas sebagai bahan pengemas benih tetapi fungsinya hanya sebagai wadah bagi benih yang dikemas untuk jumlah tertentu dan tidak melindungi benih dari pengaruh buruk kondisi penyimpanan. Plastik polipropilen sebagai bahan pengemas benih yang bersifat resisten terhadap kelembaban, dapat ditutup rapat dengan sistem perekat panas, mempunyai sifat tahan pecah dan tahan sobek. Aluminium foil merupakan kemasan simpan kedap uap air dan gas yang tahan terhadap pengaruh kelembaban dari luar kemasan sehingga dapat melindungi mutu fisik dan fisiologis benih (Esty dan Widajati, 2007).

Penelitian ini bertujuan untuk mempertahankan kualitas viabilitas benih kelengkeng selama 30 hari penyimpanan dengan kombinasi jenis bahan pelapis yang ditambahkan ekstrak biji selasih dengan wadah simpan yang berbeda.

\section{Materi}

\section{MATERI DAN METODE}

Penelitian telah dilaksanakan pada tanggal 18 November 2016 sampai dengan 23 Januari 2017 di Food Technology Laboratory, UPT Laboratorium Terpadu, Laboratorium Fisiologi dan Pemuliaan Tanaman dan Green House, Departemen Pertanian, Fakultas Peternakan dan Pertanian, Universitas Diponegoro Semarang. Materi yang digunakan antara lain pasir sebagai 
media tanam, selasih biji kemangi (Ocimum basilicum var. L.), benih kelengkeng, etanol 96\%, asam sulfat $0,05 \mathrm{~N}$, aquades, alginat, $\mathrm{CMC}$, arabic gum, bak untuk penanaman benih, alumunium foil, plastik poripropilen, dan kertas buram coklat dan gliserol.

\section{Metode}

Rancangan yang digunakan dalam penelitian ini adalah Rancangan Acak Lengkap (RAL) pola faktorial $4 \times 3$ dengan empat kali ulangan, faktor pertama yaitu pengaruh pelapisan benih (T) dengan perlakuan (T1) kontrol, (T2) Arabic gum + ekstrak biji selasih, (T3) Alginat + ekstrak biji selasih, (T4) Carboxyl Methyl Cellulose (CMC) + ekstrak biji selasih. Faktor kedua wadah simpan (P) yaitu kertas buram coklat (P1), plastik poripropilen (P2), dan alumunium foil (P3). Parameter yang diamati dalam penelitian ini yaitu 1) kadar air benih, 2) daya berkecambah, 3) indeks vigor, dan 4) potensi tumbuh maksimum. Data yang telah diperoleh diolah secara statistik berdasarkan prosedur analisis ragam (uji $\mathrm{F}$ ). Apabila terdapat pengaruh perlakuan ( $\mathrm{F}$ hitung $>$ F tabel), maka dilanjutkan dengan uji lanjut Duncan Multiple Range Test (DMRT) pada taraf $5 \%$.

\section{HASIL DAN PEMBAHASAN}

\section{Kadar Air Benih}

Hasil analisis ragam menunjukkan terdapat pengaruh interaksi perlakuan formulasi pelapisan dan wadah simpan terhadap kadar air benih kelengkeng. Perbedaan perlakuan formulasi pelapisan benih dan wadah simpan juga berpengaruh nyata terhadap kadar air benih kelengkeng. Kadar air benih merupakan cara untuk mengetahui potensi kemampuan benih berecambah setelah penanganan yang optimal sehingga mendapatkan hasil benih yang berkecambah dengan baik saat persemaian. Kadar air benih kelengkeng pada perlakuan formulasi pelapisan dan wadah simpan tersaji pada Tabel 1 .

Hasil uji lanjut Duncan Multiple Range Test menunjukkan bahwa perlakuan formulasi pelapisan Carboxyl Methyl Cellulose dengan ektrak biji selasih pada wadah simpan alumunium foil dapat mempertahankan kadar air benih kelengkeng setelah penyimpanan yang baik sebesar $47,68 \%$, yang tidak berbeda nyata dengan perlakuan alginat $47,1 \%$, namun berbeda nyata dengan perlakuan lainnya. Kadar air awal benih kelengkeng sebelum penyimpanan yaitu sebesar

Tabel 1. Kadar Air Benih Kelengkeng pada Perlakuan Formulasi Pelapisan dan Wadah Simpan

\begin{tabular}{|c|c|c|c|c|}
\hline \multirow[b]{2}{*}{ Formula Pelapisan } & \multicolumn{3}{|c|}{ Wadah Simpan } & \multirow[b]{2}{*}{ Rerata } \\
\hline & $\begin{array}{c}\text { Kertas Buram } \\
\text { Coklat } \\
\text { (P1) }\end{array}$ & $\begin{array}{c}\text { Plastik } \\
\text { Poripropilen } \\
\text { (P2) }\end{array}$ & $\begin{array}{l}\text { Alumunium } \\
\text { foil } \\
\text { (P3) }\end{array}$ & \\
\hline & \multicolumn{4}{|c|}{ - } \\
\hline T1 (Kontrol) & $36,52^{\mathrm{g}}$ & $40,36^{\mathrm{e}}$ & 39,79 ef & $38,88^{\mathrm{d}}$ \\
\hline $\begin{array}{l}\text { T2 (Arabic gum }+ \\
\text { ekstrak biji selasih) }\end{array}$ & $39,11^{\mathrm{f}}$ & $44,78^{\mathrm{d}}$ & $45,81^{\mathrm{cd}}$ & $43,23^{\circ}$ \\
\hline $\begin{array}{l}\text { T3 (Alginat + ekstrak } \\
\text { biji selasih) }\end{array}$ & $39,07^{\mathrm{f}}$ & $45,81^{\mathrm{cd}}$ & $47,10^{\mathrm{ab}}$ & $43,99^{b}$ \\
\hline $\begin{array}{l}\text { T4 (Carboxyl Methyl } \\
\text { Cellulose (CMC) + } \\
\text { ekstrak biji selasih)) }\end{array}$ & 39,83 ef & $46,55^{\text {bc }}$ & $47,68^{\mathrm{a}}$ & $44,68^{\text {a }}$ \\
\hline Rerata & $36,62^{\mathrm{c}}$ & $44,37^{\mathrm{b}}$ & $45,09^{\mathrm{a}}$ & \\
\hline
\end{tabular}

- Superskrip yang berbeda pada kolom atau baris rerata yang sama menunjukkan beda nyata $(p<0,05)$

- Superskrip yang berbeda pada matrik interaksi menunjukkan beda nyata $(\mathrm{p}<0,05)$ 
48,12\%. Hal ini menunjukkan bahwa perlakuan formulasi pelapisan Carboxyl Methyl Cellulose dapat mempertahankan kadar air benih kelengkeng dengan benih yang dilindungi oleh formulasi pelapisan tersebut yang disimpan pada alumunium foil. Carboxyl Methyl Cellulose merupakan karbohidrat stabil yang dapat digunakan sebagai zat pembawa yang baik, sehingga mampu melapisi benih secara kompak dan merata untuk melindungi benih (Tantri et al., 2013). Sedangkan jenis kemasan alumunium foil nyata lebih baik dibanding kemasan lainnya dalam mempertahankan kadar air benih kedelai yang disimpan selama 4 bulan pada suhu $16{ }^{\circ} \mathrm{C}$ dengan kelembaban/ Relative Humidity (RH) $65 \%$ (Chuansin et al., 2006).

Hasil kadar air benih kelengkeng pada perlakuan formulasi pelapisan yaitu perlakuan yang menggunakan formulasi pelapisan CMC, alginat dan arabic gum menunjukkan hasil yang berbeda nyata dengan kontrol. Hal ini menunjukkan bahwa pemberian pelapisan benih dapat melindungi benih selama penyimpanan sehingga dapat mempertahankan kadar air benih. Pemberian pelapisan benih merupakan proses pembungkusan benih dengan zat tertentu yang bertujuan untuk meningkatkan kinerja benih selama perkecambahan, melindungi benih dari gangguan atau pengaruh kondisi lingkungan, dan mempertahankan kadar air benih (Kuswanto, 2003).

Kadar air benih kelengkeng tertinggi pada wadah simpan yaitu alumunium foil dengan rerata sebesar 45,09\%. Kemasan yang baik dan tepat dapat menciptakan ekosistem ruang simpan yang baik bagi benih dan dapat mempertahankan kadar air benih sehingga benih dapat disimpan lebih lama untuk dikecambahkan. Wadah simpan memiliki uji kemampuan untuk mempertahankan kadar air benih kelengkeng. Kadar air merupakan tolak ukur untuk daya berkecambah benih, dengan kemasan alumunium foil benih kelengkeng mampu mempertahankan kadar air benih selama penyimpanan. Penggunaan wadah simpan alumunium foil merupakan kemasan yang baik dan tepat dapat melindungi benih yang dapat mempertahankan kadar air benih. Kemasan yang baik dan tepat dapat menciptakan ekosistem ruang simpan yang baik bagi benih dan dapat mempertahankan kadar air benih sehingga benih dapat disimpan lebih lama untuk dikecambahkan (Oktralixon et al., 2015).

\section{Daya Berkecambah Benih Kelengkeng}

Hasil analisis ragam menunjukkan terdapat pengaruh interaksi perlakuan formulasi pelapisan dan wadah simpan terhadap daya berkecambah benih kelengkeng. Perbedaan perlakuan formulasi pelapisan benih dan wadah simpan juga berpengaruh nyata terhadap daya berkecambah benih kelengkeng. Daya berkecambah merupakan cara untuk mengetahui kemampuan viabilitas benih setelah perlakuan yang optimal sehingga mendapatkan hasil benih yang berkecambah dengan baik saat persemaian. Daya berkecambah benih kelengkeng pada perlakuan formulasi pelapisan dan wadah simpan tersaji pada Tabel 2.

Hasil uji lanjut Duncan Multiple Range Test menunjukkan bahwa perlakuan formulasi pelapisan pada wadah simpan alumunium foil untuk daya berecambah kelengkeng menunjukkan hasil bahwa perlakuan Carboxyl Methyl Cellulose dengan ektrak biji selasih dengan hasil paling tinggi dibandingkan perlakuan lainnya yaitu sebesar $83,75 \%$. Benih dapat mengalami proses respirasi selama masa penyimpanan, sehingga dapat menurunkan viabilitas benih kelengkeng. Benih yang dilapisi menggunakan formulasi pelapisan Carboxyl Methyl Cellulose yang disimpan pada wadah simpan alumunium foil dapat menghambat terjadinya proses respirasi, karena hasil daya berkecambah benih kelengkeng yang baik. Perkecambahan benih dipengaruhi oleh proses keseimbangan antara benih dan uap air akibat kelembaban udara yang tinggi serta proses repirasi benih (Usep dan Zebua, 2005). Penyimpanan benih pada wadah simpan yang baik dan pemberian Carboxyl Methyl Cellulose pada benih bersifat baik sebagai bahan penebal, zat inert, dan sebagai pengikat serta berdasarkan fungsinya $\mathrm{CMC}$ dapat dijadikan sebagai bahan pelapis benih untuk menghambat proses respirasi benih yang dapat mempertahankan viabilitas benih (Netty, 2010).

Hasil daya berkecambah benih kelengkeng yang tinggi yaitu pada perlakuan formulasi pelapisan CMC dengan ektrak biji selasih yaitu sebesar 62,92 \%. Hal tersebut menunjukkan bahwa penggunaan pelapis benih $\mathrm{CMC}$ yang 
Tabel 2. Daya Berkecambah Benih Kelengkeng pada Perlakuan Formulasi Pelapisan dan Wadah Simpan

\begin{tabular}{|c|c|c|c|c|}
\hline \multirow[b]{2}{*}{ Formula Pelapisan } & \multicolumn{3}{|c|}{ Wadah Simpan } & \multirow[b]{2}{*}{ Rerata } \\
\hline & $\begin{array}{c}\text { Kertas Buram } \\
\text { Coklat } \\
\text { (P1) }\end{array}$ & $\begin{array}{c}\text { Plastik } \\
\text { Poripropilen } \\
\text { (P2) }\end{array}$ & $\begin{array}{l}\text { Alumunium } \\
\text { foil } \\
\text { (P3) }\end{array}$ & \\
\hline T1 (Kontrol) & $12,50^{\mathrm{e}}$ & $32,30^{\mathrm{cd}}$ & $30,00^{\text {cd }}$ & $25,00^{\circ}$ \\
\hline $\begin{array}{l}\text { T2 (Arabic gum }+ \\
\text { ekstrak biji selasih) }\end{array}$ & $7,50^{\mathrm{e}}$ & $48,75^{\text {bc }}$ & $71,25^{a b}$ & $42,50^{b}$ \\
\hline $\begin{array}{l}\text { T3 (Alginat + ekstrak } \\
\text { biji selasih) }\end{array}$ & $27,50^{\mathrm{d}}$ & $68,75^{\mathrm{ab}}$ & $71,25^{a b}$ & $55,83^{\mathrm{a}}$ \\
\hline $\begin{array}{l}\text { T4 (Carboxyl Methyl } \\
\text { Cellulose (CMC) + } \\
\text { ekstrak biji selasih)) }\end{array}$ & $43,75^{\mathrm{bcd}}$ & $61,25^{a b}$ & $83,75^{\mathrm{a}}$ & $62,92^{a}$ \\
\hline Rerata & $22,81^{\mathrm{c}}$ & $52,81^{\mathrm{a}}$ & $64,06^{\mathrm{a}}$ & \\
\hline
\end{tabular}

ditambahkan ekstrak biji selasih mampu menunjukkan hasil yang baik pada daya berkecambah benih kelengkeng. Menurut Sudirman (2012) bahwa proses respirasi akan semakin cepat pada benih saat penyimpanan yang membuat semakin banyaknya $\mathrm{CO}_{2}$, air dan panas sehingga menyebabkan semakin tingginya kadar air yang membuat daya berkecambah benih juga menurun. Penggunaan Carboxyl Methyl Cellulose sebagai pelapis benih merupakan bahan pelapis yang paling tebal ketika dihomogen dengan ekstrak biji selasih, hal tersebut dapat membuat proses respirasi terhambat.

Daya berkecambah benih kelengkeng yang tinggi pada wadah simpan yaitu alumunium foil dengan rerata sebesar 64,06 \%. Penggunaan masing-masing wadah simpan memiliki uji kemampuan untuk mempertahankan viabilitas benih kelengkeng dengan hasil daya berkecambah yang berbeda. Kadar air merupakan tolak ukur untuk daya berkecambah benih, dengan kemasan alumunium foil benih kelengkeng mampu mempertahankan viabilitas benih selama penyimpanan. Aluminium foil merupakan kemasan simpan kedap uap air dan gas yang tahan terhadap pengaruh kelembaban dari luar kemasan sehingga dapat melindungi mutu fisik dan fisiologis benih (Esty dan Widajati, 2007).
Kemasan yang baik dan tepat dapat menciptakan ekosistem ruang simpan yang baik bagi benih dan dapat mempertahankan kadar air benih sehingga benih dapat disimpan lebih lama untuk dikecambahkan.

\section{Indeks Vigor}

Hasil analisis ragam menunjukkan bahwa tidak terdapat interaksi antara penggunaan formulasi pelapisan dengan wadah simpan terhadap indeks vigor benih kelengkeng. Perbedaan perlakuan formulasi pelapisan benih dan wadah simpan juga berpengaruh nyata terhadap indeks vigor benih kelengkeng. Indeks vigor benih kelengkeng pada perlakuan formulasi pelapisan dan wadah simpan tersaji pada Tabel 3.

Hasil indeks vigor benih kelengkeng tertinggi pada perlakuan formulasi pelapisan yaitu Carboxyl Methyl Cellulose dengan ektrak biji selasih yaitu sebesar 40,42 \%. Perkecambahan benih dapat terjadi saat penyimpanan karena benih mengalami proses imbibisi yaitu masuknya air kedalam benih yang memicu terjadinya perkecambahan karena adanya aktivitas enzim pada benih saat penyimpanan. Perkecambahan benih di picu dengan proses imbibisi, yaitu masuknya air ke dalam benih sehingga memicu 
Tabel 3. Indeks Vigor Benih Kelengkeng pada Perlakuan Formulasi Pelapisan dan Wadah Simpan

\begin{tabular}{|c|c|c|c|c|}
\hline \multirow[b]{2}{*}{ Formula Pelapisan } & \multicolumn{3}{|c|}{ Wadah Simpan } & \multirow[b]{2}{*}{ Rerata } \\
\hline & $\begin{array}{c}\text { Kertas Buram } \\
\text { Coklat } \\
(\mathrm{P} 1) \\
\end{array}$ & $\begin{array}{c}\text { Plastik } \\
\text { Poripropilen } \\
\text { (P2) }\end{array}$ & $\begin{array}{l}\text { Alumunium } \\
\text { foil } \\
\text { (P3) }\end{array}$ & \\
\hline & \multicolumn{4}{|c|}{ 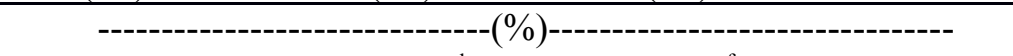 } \\
\hline T1 (Kontrol) & $10,00^{\mathrm{g}}$ & $26,25^{\text {cde }}$ & $20,00^{\text {ef }}$ & $18,75^{\mathrm{c}}$ \\
\hline $\begin{array}{l}\text { T2 (Arabic gum }+ \\
\text { ekstrak biji selasih) }\end{array}$ & $13,75^{\mathrm{fg}}$ & $33,75^{\mathrm{bcd}}$ & $42,50^{a b}$ & $30,00^{b}$ \\
\hline $\begin{array}{l}\text { T3 (Alginat }+ \text { ekstrak } \\
\text { biji selasih) }\end{array}$ & $27,50^{\text {cde }}$ & $43,75^{\mathrm{ab}}$ & 37,50 bc & $36,25^{\mathrm{a}}$ \\
\hline $\begin{array}{l}\text { T4 (Carboxyl Methyl } \\
\text { Cellulose (CMC) + } \\
\text { ekstrak biji selasih)) }\end{array}$ & $25,00^{\text {de }}$ & $42,50^{\mathrm{ab}}$ & $53,75^{\text {a }}$ & $40,42^{\mathrm{a}}$ \\
\hline Rerata & $19,06^{\mathrm{b}}$ & $36,56^{\mathrm{a}}$ & $38,44^{\mathrm{a}}$ & \\
\hline
\end{tabular}

terjadinya perkecambahan karena adanya aktivasi kerja enzim yang akan di pergunakan untuk merombak cadangan makanan dan ditranslokasikan ke titik tumbuh pada benih yang kemudian tumbuh menjadi kecambah (Bradford dan Nonogaki, 2007). Hal tersebut menunjukkan bahwa perlakuan formulasi pelapisan memiliki manfaat untuk menjaga benih dari proses imbibisi sehingga viabilitas benih pada hasil indeks vigor. Hal ini sesuai pendapat Ilyas (2012) bahwa formulasi pelapisan merupakan solusi untuk mempertahankan viabilitas benih, formulasi pelapisan benih yang baik adalah Carboxyl Methyl Cellulose.

Hasil indeks vigor benih kelengkeng yang tinggi pada perlakuan wadah simpan yaitu alumunium foil dengan rerata sebesar 38,44\%, sedangkan wadah simpan pada kertas buram coklat menunjukkan hasil indeks vigor yang rendah yaitu 19,06 \%. Wadah simpan menggunakan kertas buram coklat sangat mengurangi kadar air benih kelengkeng yang termasuk benih rekalsitran, hal tersebut membuat terjadinya penurunan kadar air benih kelengkeng yang berpengaruh pada indeks vigor benih. Menurut Heri (2013) bahwa benih yang simpan pada Dry Cold Storage (DCS) dengan lama penyimpanan minggu ke 6 dengan bahan kemasan kertas buram coklat menunjukkan hasil kadar air terendah sebesar $4.19 \%$, sehingga menghasilkan indeks vigor benih terendah dibandingkan wadah simpan lainnya.

\section{Potensi Tumbuh Maksimum Benih Kelengkeng}

Hasil analisis ragam menunjukkan bahwa terdapat interaksi antara penggunaan formulasi pelapisan dengan wadah simpan terhadap potensi tumbuh maksimum benih kelengkeng. Perbedaan perlakuan formulasi pelapisan benih dan wadah simpan juga berpengaruh nyata terhadap potensi tumbuh maksimum benih kelengkeng. Potensi tumbuh maksimum benih kelengkeng pada perlakuan formulasi pelapisan dan wadah simpan tersaji pada Tabel 4.

Hasil uji lanjut Duncan Multiple Range Test menunjukkan bahwa perlakuan formulasi pelapisan pada wadah simpan alumunium foil untuk potensi tumbuh maksimum benih kelengkeng menunjukkan hasil yang baik yaitu perlakuan Carboxyl Methyl Cellulose dengan ektrak biji selasih dengan hasil sebesar $90 \%$ yang tidak berbeda nyata dengan formulasi pelapisan arabic gum yaitu sebesar 75,00, namun berbeda nyata dengan perlakuan alginat dan kontrol. Benih kelengkeng memiliki membran sel yang dapat 
Tabel 4. Potensi Tumbuh Maksimum Benih Kelengkeng pada Perlakuan Formulasi Pelapisan dan Wadah Simpan

\begin{tabular}{|c|c|c|c|c|}
\hline \multirow[b]{2}{*}{ Formula Pelapisan } & \multicolumn{3}{|c|}{ Wadah Simpan } & \multirow[b]{2}{*}{ Rerata } \\
\hline & $\begin{array}{c}\text { Kertas Buram } \\
\text { Coklat } \\
(\mathrm{P} 1) \\
\end{array}$ & $\begin{array}{c}\text { Plastik } \\
\text { Poripropilen } \\
\text { (P2) } \\
\end{array}$ & $\begin{array}{l}\text { Alumunium } \\
\text { foil } \\
\text { (P3) }\end{array}$ & \\
\hline T1 (Kontrol) & $20,00^{\mathrm{f}}$ & 37,50 e & $36,25^{\mathrm{e}}$ & $31,25^{\mathrm{c}}$ \\
\hline $\begin{array}{l}\text { T2 (Arabic gum }+ \\
\text { ekstrak biji selasih) }\end{array}$ & $17,50^{\mathrm{f}}$ & $56,25^{\mathrm{cd}}$ & $75,00^{a b}$ & $45,58^{\mathrm{b}}$ \\
\hline $\begin{array}{l}\text { T3 (Alginat + ekstrak } \\
\text { biji selasih) }\end{array}$ & $35,00^{\mathrm{e}}$ & 76,25 ab & $73,75^{\mathrm{b}}$ & $61,67^{a}$ \\
\hline $\begin{array}{l}\text { T4 (Carboxyl Methyl } \\
\text { Cellulose (CMC) }+ \\
\text { ekstrak biji selasih)) }\end{array}$ & 50,00 de & 66,25 bc & $90,00^{\text {a }}$ & $68,75^{a}$ \\
\hline Rerata & $30,63^{\mathrm{c}}$ & $59,06^{\text {b }}$ & $68,75^{a}$ & \\
\hline
\end{tabular}

- Superskrip yang berbeda pada kolom atau baris rerata yang sama menunjukkan beda nyata $(\mathrm{p}<0,05)$

- Superskrip yang berbeda pada matrik interaksi menunjukkan beda nyata $(\mathrm{p}<0,05)$

mempengaruhi keaadaan embrio dan kotiledon saat penyimpanan, apabila terjadi kebocoran membran sel saat penyimpanan akan menyebabkan penurunan viabilitas benih kelengkeng akibat terjadinya kerusakan pada embrio dan kotiledon pada benih lengkeng ketika dikecambahkan. Menurut Sudirman (2012) bahwa kebocoran membran sel akibat deteriorasi menyebabkan penurunan viabilitas benih yang dipercepat. Kerusakan membran sel akibat deteriorasi akan mempengaruhi keadaan embrio dan kotiledon yang sebagian besar terdiri atas karbohidrat, protein dan lemak yang berguna untuk pertumbuhan awal. Hasil dari potensi tumbuh benih kelengkeng tersebut menunjukkan perbedaan yang tinggi dari semua perlakuan formulasi dibandingkan dengan perlakuan kontrol. Menurut Copeland dan McDonald (1995) bahwa pelapisan benih merupakan salah satu metode untuk memperbaiki mutu benih menjadi lebih baik dengan penambahan bahan kimia pada formula pelapisan. Pelapisan benih dapat mengendalikan dan meningkatkan perkecambahan serta berpotensi digunakan untuk inokulasi benih dengan mikroorganisme hidup, dapat melindungi benih dari hama dan penyakit tanaman yang menyerang saat persemaian dan awal musim tanam, meningkatkan vigor bibit, serta mengurangi penggunaan pestisida saat menanam tanaman.

Hasil potensi tumbuh maksimum benih kelengkeng pada perlakuan formulasi pelapisan yang baik yaitu penggunaan formulasi pelapisan Carboxyl Methyl Cellulose dengan ekstrak biji selasih yaitu sebesar 68,75 \%. Hal tersebut menunjukkan bahwa Carboxyl Methyl Cellulose dapat mempertahankan viabilitas benih yang paling baik. Carboxyl Methyl Cellulose memiliki peran sebagai bahan higroskopis yang mampu mempertahankan viabilitas benih selama penyimpanan (Susanti, 2014). Penelitian yang dilakukan oleh Tantri et al. (2013) bahwa formulasi dengan menggunakan alginat telah dilakukan dan di peroleh hasil bahwa dengan perlakuan pelapisan dengan alginat merupakan perlakuan terbaik dalam meningkatkan hasil tanaman berdasarkan persentase bobot dan jumlah gabah bernas tertinggi serta persentase bobot gabah hampa per malai.

Potensi tumbuh maksimum benih kelengkeng tertinggi pada wadah simpan yaitu alumunium foil dengan rerata sebesar $68,75 \%$. Alumunium foil 
sebagai wadah simpan terbaik yang mampu mempertahankan viabilitas benih karena sifat kekedapan udara dari wadah simpan alumunium foil tersebut. Hal ini sesuai pendapat Robi'in (2007) bahwa sifat kekedapan udara maupun uap air pada aluminum foil lebih baik dibanding plastik tetapi dari segi kekuatan dan keelastisan, aluminum foil mudah sobek.

\section{KESIMPULAN}

Hasil penelitian dapat disimpulkan bahwa perlakuan formulasi pelapisan Carboxyl Methyl Cellulose dengan ekstrak biji selasih dan wadah simpan alumunium foil memberikan hasil yang terbaik pada semua paramater penelitian untuk mempertahankan viabilitas benih kelengkeng yang disimpan selama 30 hari. Pelapisan benih dengan menggunakan Carboxyl Methyl Cellulose dengan ekstrak biji selasih menunjukkan hasil tertinggi pada semua parameter penelitian untuk viabilitas benih kelengkeng yang disimpan selama 30 hari. Wadah simpan dengan menggunakan alumunium foil menunjukkan hasil tertinggi pada semua parameter penelitian untuk viabilitas benih kelengkeng yang disimpan selama 30 hari.

\section{DAFTAR PUSTAKA}

Badan Karantina Pertanian (Barantan). 2014. Laporan Tahunan Badan Karantina Pertanian Tahun 2013. Jakarta.

Balai Besar Karantina Pertanian Surabaya. 2014. Laporan Tahunan Balai Besar Karantina Pertanian Surabaya Tahun 2013. Surabaya.

Bradford, K.J dan H. Nonogaki. 2007. Seed development, dormancy, and germination. Blackwell. Oxford.

Chuansin, S., S. Vearaslip, S. Srichuwong, E.Pawelzik. 2006. Selection of Packaging Materials for Soybean seed storage. (Online) http://www.tropentang.de/2006/abstract/full/ 229.pdf [15 Maret 2017].

Copeland, L.O., and M.B. McDonald. 1995. Principles of Seed Science and Technology, 3rd edition. Chapman and Hall. New York.
Dita, F.S. 2011. Pemanfaatan Rimpang Jahe dalam Penyimpanan Benih Lengkeng (Dimocarpus longan Lour). Fakultas Pertanian. Universitas Sebelas Maret. Skripsi:tidak dipublikasikan.

Esti R. dan E. Widajati. 2007. Pengaruh kemasan, kondisi ruang simpan dan periode simpan terhadap viabilitas benih caisin (Brassica chinensis L.). J. Agron. Indonesia 35 (3) : $191-196$.

Harmely, F., D. Chris, dan S. Y. Wisnu. 2014. Formulasi dan evaluasi sediaan edible film dari ekstrak daun kemangi (Ocimum americanum L.) sebagai penyegar mulut. Jurnal Sains Farmasi dan Klinis 1 (1) : 3847.

Heri S. 2013. Pengaruh beberapa perlakuan penyimpanan terhadap perkecambahan benih suren (Toona sureni). Jurnal Penelitian Kehutanan Wallacea 2 (1) : 26-40.

Ilyas, S. 2012. Ilmu dan Teknologi Benih. Teori dan Hasil-hasil Penelitian. IPB Press. Bogor.

Kuswanto, H. 2003. Teknologi Pemrosesan, Pengemasan, dan Penyimpanan Benih. Kanisius. Yogyakarta.

Netty K. 2010. Pengaruh bahan aditif CMC (Carboxyl Methyl Cellulose) terhadap beberapa parameter pada larutan sukrosa. Jurnal Teknologi 1 (17) : 78-84.

Oktralixon L., Y. Tambing, dan Adrianton. 2015. Peranan kemasan dan media simpan terhadap ketahanan viabilitas dan vigor benih nangka (Artocarpus heterophyllus lamk) kultivar tulo-5 selama penyimpanan. Jurnal Agrotekbis 3 (3) : 303 - 315 .

Rina, D. P., R. Rohmanti, dan A. Purwantoro. 2012. Pengaruh jenis dan kadar air media simpan terhadap viabilitas benih lengkeng (Dimocarpus longan Lour.). J. Vegetalika 1 (2) : $1-6$. 
Robi'in. 2007. Perbedaan Bahan Kemasan dan Periode Simpan dan Pengaruhnya Terhadap Kadar Air Benih Jagung dalam Ruang Simpan Terbuka. www.pustakadeptan.go.id/publikasi/bt121073.pdf $[15$ Maret 2017].

Sudirman, U. 2012. Pengaruh pemberian bahan organik terhadap daya simpan benih kedelai (Glycine $\max$ L. Merr.). Jurnal Berita Biologi 11 (3) : 401-410.

Susanti, H. 2014. Pengaruh berbagai bahan coating dan bahan aditif pada benih kedelai (Glycine $\max$ L. Merril) untuk mempertahankan viabilitas dan vigor benih selama penyimpanan. Jurusan Agroteknologi, Fakultas Pertanian, Universitas Lampung. Lampung Barat.
Skripsi (tidak dipublikasikan).

Tantri P., S. Ilyas, M. Machmud, dan E. Widajati. 2013. Coating benih dengan agen hayati untuk meningkatkan pertumbuhan dan hasil tanaman padi. J. Agron. Indonesia 41 (3) : $175-180$.

Usep S. dan Zebua I. L. 2005. Excised embryo rambutan (Nephelium lappaceum L.) dan kepekaannya terhadap pengeringan. Jurnal Berita Biologi 7 (4) : 223-228.

Widyawati, N., P. Tohari., I. Yudono, dan Soemardi. 2009. Permeabilitas dan perkecambahan benih Aren (Arenga pinnata (Wurmb.) Merr.). J. Agron. Indonesia 37 (2) : 152-158. 